\title{
RECENZJE
}

\section{Hermann Cohen i początki szkoły marburskiej}

Hartwig Wiedebach jest związanym z Hermann-Cohen-Archiv z siedzibą w Zurychu, badaczem filozofii niemieckiej zorientowanym na problemy judaizmu, a swoim głównym przedmiotem rozważań czyni filozofię twórcy neokantowskiej szkoły marburskiej, Hermanna Cohena. Wiedebach współpracuje z Helmutem Holzheyem nad wydaniem dzieł Hermanna Cohena (Hermann Cohen Werke), a wydanie to uzupełnia o dwutomowe Supplementa (Reflexionen und Notizien). Rezultatem jego pracy naukowej są dwie niezwykle ważne rozprawy, a mianowicie Die Bedeutung der Nationalität für Hermann Cohen (Hildesheim-Zürich-New York 1997; wydanie angielskie - The National Element in Hermann Cohen's Philosophy and Religion; Leiden-Boston 2012) oraz "Kreuz der Wirklichkeit” und „Stern der Erlösung”. Die Glaubens-Metaphysik Eugen Rosenstock-Huessy und Franz Rosenzweig (Freiburg 2010). Wiedebach jest zatem badaczem przygotowanym do wydania korespondencji Hermanna Cohena.

Adresatem listów Cohena jest August Stadler, uczeń, a później przyjaciel filozofa z Marburga. Książka zawiera 64 listy, a Cohen jest autorem 63 spośród nich. Jeden list jest adresowany do berlińskiego wydawnictwa Ferdinand Dümmler, jeden list zawiera odpowiedź wydawnictwa, zaś 62 listy są skierowane do Stadlera. Zaprezentowana korespondencja jest interesująca z kilku powodów. Po pierwsze, prezentowana korespondencja jest interesująca dlatego, że jej autorem jest jeden z najwybitniejszych neokantystów, który dokonuje znaczącej interpretacji filozofii Kanta i znajomość, a później przyjaźń ze Stadlerem rozpoczęła się w rezultacie opublikowania przez Cohena pierwszego wydania Kants Theorie der Erfahrung (Berlin 1871). Po drugie, ze względu na osobę adresata, profesora Politechniki Zuryskiej w latach 1892-1910. Politechnika została założona w roku 1854, zaś dziś 
znana jest jako Eidgenössische Technische Hochschule (ETH Zürich). Po trzecie, ze względu na okres, jaki korespondencja obejmuje. Listy zasadniczo datowane są między 8 maja 1872 a 30 października 1881, chociaż na końcu wydawca umieścił 6 listów napisanych pomiędzy 8 maja 1886 a 29 grudnia 1905, które jednak były już publikowane w roku 1939 w korespondencji Hermanna Cohena wydanej przez Berthę i Brunona Strauß. Po czwarte wreszcie, co w istotny sposób związane jest z czasem, w którym Cohen pisze swe listy, stanowią one wyśmienity dowód ewolucji myślenia twórcy szkoły marburskiej. Dość powiedzieć, że nazwisko Paula Natorpa, współtwórcy szkoły marburskiej, pojawia się dopiero na końcu korespondencji ${ }^{1}$.

August Stadler (1850-1910) pojawił się u Cohena z polecenia Friedricha Alberta Langego w kwietniu 1872 roku $^{2}$, a przyczyną była książka Kants Theorie der Erfahrung. Walter Kinkel (1871-1937), przyjaciel i biograf Cohena, profesor filozofii w oddalonym ok. $30 \mathrm{~km}$ od Marburga Gießen, przywołuje następującą sytuację: „Jeden profesor filozofii, którego nazwisko nie ma tu nic do rzeczy, stwierdził, że »Kantowska krytyka czystego rozumu« stanowi całkiem dobry komentarz do »teorii doświadczenia « Cohena" ${ }^{3}$. Filozofem tym miał być Lange, a prawdą jest, co zresztą przyczyniło się ostatecznie do znajomości Stadlera z Cohenem, że Lange bardzo wysoko cenił książkę Cohena i w swej Historii materializmu pisze: „Decydujące znaczenie ma jednak zwłaszcza książka: Kantowska teoria doświadczenia, dr Hermann Cohen, Berlin 1871, ponieważ tutaj po raz pierwszy cała energia intensywnej pracy została spożytkowana na to, aby całkowicie opanować terminologię Kanta i w ten sposób za pomocą najbardziej dokładnego określenia pojęcia wniknąć głębiej w sens filozofa; postępowanie, którego bezwarunkowa konieczność mogła zostać każdemu otwarcie przedstawiona dopiero dzięki osobliwemu sporowi Trendelenburga i Kunona Fischera" 4.

Przedstawiona przez Langego ocena książki Cohena zaowocowała nie tylko listem polecającym do Cohena, ale także umożliwieniem Cohenowi habilitacji, kiedy zawiodła próba habilitowania się w Berlinie. Podstawą habilitacji miała być książka Kants Theorie der Erfahrung, ale zarówno Friedrich Albert Trendelenburg (1802-1872), jak i Friedrich Harms (1819-1880) uznali ja za niewystar-

\footnotetext{
1 List nr 58 z dnia 30.10.1881. Hermann Cohen. Briefe an August Stadler. Hrsg. von H. Wiedebach. Schwabe Verlag Basel 2015, s. 129-132.

2 Zob. H. Cohen: August Stadler, geb. am 24. August 1850; gest. am 16. Mai 1910. Ein Nachruf. „Kant-Studien” 1910, Bd. 15, s. 404.

3 W. Kinkel: Hermann Cohen. Sein Leben und sein Werk. Strecker und Schröder Stuttgart 1924 , s. 53 .

4 F.A. Lange: Geschichte des Materialismus und Kritik seiner Bedeutung in der Gegenwart. 2. Buch: Geschichte des Materialismus seit Kant. 2. Aufl. Baedeker Iserlohn 1875, s. 115.
} 
czającą ${ }^{5}$. Trendelenburg zmarł 24 stycznia 1872 roku i na wiosnę 1873 roku Cohen złożył wniosek o habilitację, ale uznano, że książka została już raz oceniona i nie ma podstaw do ponownego podjęcia próby. Peter A. Schmid uważa, że w tym wypadku - co miało miejsce 4 marca 1873 - Cohen złożył również rękopis książki poświęconej etyce, która ukazała się kilka lat później ${ }^{6}$. Dodatkowo skomplikowały się sprawy osobiste Cohena, gdyż w kwietniu 1873 roku zmarła mu matka. Za sprawą Stadlera o wszystkim dowiedział się Lange i wsparł próbę habilitowania się w Marburgu. Cohen dostarczył rękopis pracy poświęconej pismom przedkrytycznym Kanta, która pierwotnie była zatytułowana Kants vorkritische Schriften in ihrem Verhältniss zum kritischen Idealismus, a ponadto pracę, która była oceniona już w Berlinie, a mianowicie Kants Theorie der Erfahrung. Recenzentami dorobku zostali Georg Weißenborn (1806-1874) oraz Lange i okazało się, że od początku nie byli oni zgodni w ocenie przedstawionego dorobku, a kością niezgody stała się osoba Kunona Fischera. Weißenborn miał Cohenowi za złe polemikę z Fischerem, natomiast Lange jego krytykę Fischera uważał za znakomitą. Lange zresztą w ogóle był przekonany, że Kuno Fischer jest jednym z najbardziej przecenionych filozofów tamtych czasów ${ }^{7}$. Stanęło na tym, że Cohen złagodzi nieco swe stanowisko, a kiedy to nastąpiło, wówczas praca ukazała się pod zmienionym tytułem w październiku 1873 roku. Teraz nosiła ona tytuł Die systematischen Begriffe in Kants vorkritischen Schriften nach ihrem Verhältniss zum kritischen Idealismus $^{8}$. 16 października 1873 roku odbył się egzamin, 6 listopada zaś przyszły twórca szkoły marburskiej otrzymał venia legendi. Perypetie związane $\mathrm{z}$ kolokwium opisuje Cohen w liście $9 \mathrm{z}$ dnia 7 listopada $1873 \mathrm{roku}^{9}$. Po habilitacji Cohen pracował w Marburgu jako docent prywatny, a kiedy 4 czerwca 1874 zmarł Weißenborn, Lange starał się o katedrę dla Cohena. Stało się inaczej i 19 października 1874 roku katedrę obsadził Julius Bergmann (1839-1904). Dopiero przedwczesna śmierć Langego spowodowała konieczność obsadzenia drugiej katedry i 2 lutego 1876 roku Cohen został powołany na katedrę filozofii w Marburgu, którą zajmował do momentu przejścia na emeryturę w roku 1912.

August Stadler, jak już zaznaczono, pojawił się w Berlinie u młodego doktora, autora Kants Theorie der Erfahrung, Hermanna Cohena, co wynikało z faktu, że

\footnotetext{
5 Zob. U. Sieg: Aufstieg und Niedergang des Marburger Neukantianismus. Die Geschichte einer philosophischen Schulgemeinschaft. Königshausen \& Neumann Würzburg 1994, s. 113.

6 P.A. Schmid: Einleitung II. In: H. Cohen: Werke. Bd. 2: Kants Begründung der Ethik. 3. Aufl. Einleitung von P. Müller, P.A. Schmid. Georg Olms Hildesheim-Zürich-New York 2001, s. 26 .

7 Zob. U. Sieg: Aufstieg und Niedergang des Marburger Neukantianismus..., s. 114.

8 H. Cohen: Die systematischen Begriffe in Kants vorkritischen Schriften nach ihrem Verhältniss zum kritischen Idealismus. Ferdinand Dümmler Berlin 1873.

9 it Hermann Cohen. Briefe an August Stadler..., s. 31-36.
} 
poznał Langego. Stadler będąc studentem politechniki w rodzinnym Zurychu studiował dwa lata pod kierunkiem Gottfrieda Sempera (1803-1879), niemieckiego architekta i teoretyka sztuki. Następnie Stadler spotkał jednak Langego, który był profesorem Uniwersytetu Zuryskiego w latach 1870-1872 i w semestrze zimowym 1872/73 został powołany z Zurychu do Marburga. Stadler udał się na studia do Berlina, gdzie studiował pod kierunkiem Hermanna von Helmholtza, ale w roku 1872 brał udział w prywatnym seminarium Cohena poświęconym Krytyce czystego rozumu. Od tego czasu datuje się korespondencja między nimi pierwszy zachowany list Cohena pochodzi z 8 maja 1872 roku - oraz rodzacca się przyjaźń. W roku 1874 Stadler doktoryzował się w Zurychu na podstawie pracy poświęconej teleologii Kanta ${ }^{10}$. Już w Przedmowie Stadler zwraca uwage na znaczenie książki Cohena i pisze: „Moja rozprawa wynika z badań H. Cohena dotyczacych Kantowskiej teorii doświadczenia. Z ich rezultatów wynika dla mnie, obok właściwego zrozumienia Krytyki czystego rozumu, przede wszystkim także pocieszające przekonanie, że ten, kto zwraca się do filozofii krytycznej, nie pracuje na żadnym zbutwiałym i przestarzałym dziele" ${ }^{11}$. Przedmowa datowana jest na listopad 1873, a więc czas habilitowania się Cohena w Marburgu. Stadler nieco czasu po obronie doktoratu spędził w Anglii, a kiedy powrócił w roku 1877, wówczas habilitował się w Zurychu na politechnice. Wcześniej jednak opublikował książkę poświęconą zasadom teorii poznania ${ }^{12}$, w której znowu odnosi się do Cohena ${ }^{13}$. W roku 1892 Stadler zostaje powołany na stanowisko Politechniki Zuryskiej. W roku 1883 publikuje Stadler swoje trzecie ważne dzieło, poświęcone teorii materii ${ }^{14}$, co zbiega się z wydaniem przez Cohena książki stanowiącej próbę nowego ugruntowania idealizmu ${ }^{15}$. Cohen w nawiązaniu do tego faktu zauważa, że Stadler poznał książkę przed jej opublikowaniem, „a mimo to faktem pozostaje, że »teoria materii« została przez niego opracowana, zanim doszedłem do pełnej jasności i ostatecznego wyjaśnienia nowej zasady" 16. Stadler, skierowany do Cohena przez Langego, stał się jego uczniem, przyjacielem i powiernikiem. Dlatego tė̇ Ulrich Sieg może z czystym sumieniem napisać, że „Stadler był jednym z pierwszych zwolenników Cohena i jednym ze znaczących teoretyków neo-

10 A. Stadler: Kants Teleologie und ihre rekenntnisstheoretische Bedeutung. Eine Untersuchung. Ferdinand Dümmler Berlin 1874.

11 Ibidem, s. V.

12 A. Stadler: Die Grundsätze der reinen Erkenntnisstheorie in der Kantischen Philosophie. Kritische Darstellung. Hirzel Leipzig 1876.

13 Zob. ibidem, s. III.

14 A. Stadler: Kants Theorie der Materie. Hirzel Leipzig 1883.

15 H. Cohen: Das Princip der Infinitesimal-Methode und seine Geschichte. Ein Kapitel zur Grundlegung der Erkenntniskritik. Ferdinand Dümmler Berlin 1883.

16 H. Cohen: August Stadler..., s. 412. 
kantyzmu" 17. Jest to znaczące również dlatego, że w ten sposób korespondencja dotyka problemów neokantyzmu.

Korespondencja Hermanna Cohena jest źródłem wiedzy dotyczącej jego samego, Stadlera, Langego, a także innych filozofów. Nie idzie o zaspokojenie zwykłej ludzkiej ciekawości, ale o naświetlenie atmosfery epoki. Czytelnik dowiaduje się na przykład, że Cohen cieszy się, iż poznał osobiście Jürgena Bona Meyera ${ }^{18}$. Bona Meyer (1829-1897), kilkanaście lat starszy od Cohena, był jak on studentem Trendelenburga. Jürgen Bona Meyer ważny jest z dwóch powodów dla neokantyzmu. Po pierwsze, z powodu niezwykle ważnych dla rodzącego się ruchu filozoficznego tekstów poświęconych relacji między duszą a ciałem ${ }^{19}$. Efektem tych zmagań jest - obok cyklu artykułów poświęconych temu zagadnieniu - książka zatytułowana Zum Streit über Leib und Seele ${ }^{20}$. W związku z tą książką badacz wczesnego neokantyzmu Klaus Christian Köhnke (1953-2013) powie o Meyerze, że jest „w ogóle pierwszym neokantystą" ${ }^{21}$. Po drugie, jest Jürgen Bona Meyer ważny jako autor książki, która została opublikowana w roku 1870, a więc rok przed wydaniem przez Cohena Kants Theorie der Erfahrung, zatytułowanej Kants Psychologie 22 . Fakt ten sytuuje Meyera w nurcie neokantyzmu psychologicznego, który nawiązuje do dokonań Jakoba Friedricha Friesa (1773-1843). Najbardziej znaczącymi reprezentantami tego kierunku byli Leonard Nelson (1882-1927) oraz Hans Cornelius (1863-1947).

Dzięki udostępnieniu korespondencji czytelnik może się zapoznać z istotnymi elementami życiorysu Cohena. Należy do nich między innymi informacja o śmierci Langego, który zmarł 21 listopada 1875 roku. Skoro Cohen nie został powołany wcześniej na katedrę filozofii po Weißenbornie, to okazja ta nadarzyła się po śmierci Langego i tak też się stało. Cohen został powołany na stanowisko profesora zwyczajnego w Marburgu decyzją z dnia 22 stycznia 1876 roku, a nie 2 lutego, jak sugeruje to Ulrich $\mathrm{Sieg}^{23}$.

17 U. Sieg: Aufstieg und Niedergang des Marburger Neukantianismus..., s. 114.

18 List nr 25 z dnia 14.7.1875. Hermann Cohen. Briefe an August Stadler..., s. 69.

19 Zob. szerzej A.J. Noras: Historia neokantyzmu. Katowice 2012, s. 154-159 oraz 361-377.

20 J.B. Meyer: Zum Streit über Leib und Seele. Worte der Kritik. Sechs Vorlesungen, am Hamburger akademischen Gymnasium gehalten. Hamburg 1856.

21 K.Ch. Köhnke: Entstehung und Aufstieg des Neukantianismus. Die deutsche Universitätsphilosophie zwischen Idealismus und Positivismus. Frankfurt am Main 1993, s. 23.

22 J.B. Meyer: Kants Psychologie. Berlin 1870.

23 Zob. List nr $33 \mathrm{z}$ dnia 5.2.1876. Hermann Cohen. Briefe an August Stadler..., s. 70. Por. U. Sieg: Aufstieg und Niedergang des Marburger Neukantianismus..., s. 118. Przy czym sam Sieg wskazuje znowu na Juliusa Ebbinghausa (1885-1981), który powołanie datuje na styczeń 1876. Por. J. Ebbinghaus: Zur Berufung Cohens auf den Marburger Lehrstuhl. „Archiv für Philosophie" 1959, s. 92. 
Książka nie jest tylko zbiorem informacji dotyczących faktów z życia uczonych, ale także wprowadza czytelnika w cały szereg problemów filozoficznych. Cohen dyskutuje ze Stadlerem problem rozumienia kategorii w kontekście książki tego ostatniego. I tak na stronie 70 czytamy: „Jeśli składam Panu gratulacje z powodu ukończenia tej pracy, to zarazem ze względu na wątpliwości odnośnie szacunku, które niekiedy rozważaliśmy - w rzeczywistości są te same o niezwykle rzeczowym znaczeniu - chcę wyrazić Panu moją ogromną radość. O ile dotychczas po jednorazowym przeczytaniu wgłębiłem się w delikatne zmiany, które Pan proponuje, zdają mi się one w większości ulepszeniami, zwłaszcza to, co Pan przeciwko mnie podkreśla pod względem odczytania kategorii i rodzajów sądów" 24. Ważnym wydarzeniem była dla Cohena publikacja przez Hansa Vaihingera (1852-1933) książki poświęconej koncepcjom Eduarda von Hartmanna, Eugena Dühringa oraz Friedricha Alberta Langego ${ }^{25}$. Cohen mając na względzie przeprowadzone przez Vaihingera analizy zauważa: „Lange jest ponad innymi, tak wiele już pojąłem” 26.

Innym przykładem problemów, z jakimi musi się zmagać Cohen, jest edycja Logische Studien Langego w roku $1877^{27}$. Cohen informuje Stadlera, że nie jest zadowolony z edycji, gdyż nie akceptuje stanowiska Langego i w odniesieniu do niego stwierdza: „Niestety nie mogę w tym rozpoznać »nowego ugruntowania «" 28. Innymi słowy, Cohen jest przekonany, że stanowisko Langego w kilku kwestiach jest nie do utrzymania, a zwłaszcza jeśli idzie o rozumienie relacji między matematyką a logiką oraz w kwestii rozumienia aprioryczności. Czytelnikowi zaznajomionemu z filozofią Cohena sprawa wyda się prostsza, jeśli rozumienie aprioryczności przez Cohena powiąże z jego analizami przedstawionymi w Kants Theorie der Erfahrung, a dodatkowo zapozna się z analizami Johanna Heinricha Wittego, zawartymi w jego książce z roku 1877.

Trzeba zatem podkreślić, że obok postaci znanych pojawiają się też te, które są dzisiaj zapomniane, a które prawdopodobnie w jakimś stopniu wpłynęły na kształtowanie się filozofii Cohena. Właśnie taką postacią zdaje się być na przykład Johann Heinrich Witte (1846-1908), urodzony w Berlinie, a zmarły na Kaszubach (Preußisch Friedland; Debrzno), związany z Uniwersytetem w Bonn. Witte jest autorem dwóch ważnych rozpraw, które w jakimś sensie mogły wpłynąć na Cohena. W roku 1876 opublikował rozprawę poświęconą Salomonowi Maimonowi,

24 List nr 26 z dnia 11.8.1875. Hermann Cohen. Briefe an August Stadler..., s. 70.

25 Zob. H. Vaihinger: Hartmann, Dühring und Lange. Zur Geschichte der deutschen Philosophie im XIX. Jahrhundert. Ein kritischer Essay. Iserlohn 1876.

26 List nr 38 z dnia 26.7.1876. Hermann Cohen. Briefe an August Stadler..., s. 93.

27 F.A. Lange: Logische Studien. Ein Beitrag zur Neubegründung der formalen Logik und der Erkenntnisstheorie. Iserlohn 1877.

28 List nr 41 z dnia 1.12.1876. Hermann Cohen. Briefe an August Stadler..., s. 101. 
filozofowi pochodzenia polskiego, który swoją interpretacją Kanta wpłynął na wizję Hermanna Cohena. Cohen pisze do Stadlera, że Witte przesłał mu egzemplarz książki poświęconej Maimonowi ${ }^{29}$. Hartwig Wiedebach podkreśla ponadto, że Cohen wspomina inną książkę Wittego, chociaż nie jest pewne, o którą książkę chodzi. Faktem jednak jest, że w roku 1877 Witte opublikował książkę zatytułowaną Zur Erkenntnisstheorie und Ethik ${ }^{30}$, na którą składają się trzy rozprawy, poświęcone zagadnieniu a priori, wnioskowaniom oraz wolności.

Hartwig Wiedebach wskazuje na istotny element Cohenowskiego odczytania Kanta, który występuje w liście z 8 listopada $1877 \mathrm{roku}^{31}$. W Przedmowie do drugiego wydania Krytyki czystego rozumu Kant pisze: „[...] jeżeli nie jest możliwe pogodzić ze sobą różnych współpracowników co do tego, jak należy zmierzać do wspólnego celu, to zawsze można być przekonanym, że takie badanie wcale jeszcze nie weszło na pewną droge badania naukowego, lecz jest tylko kroczeniem po omacku” 32 . Wiedebach wskazuje, że u Kanta czytamy „den sicheren Gang einer Wissenschaft” 33 , podczas gdy Cohen nie pisze „sicher”, lecz „stetig”, a więc nie „pewny” lecz „ciągły”. Znajduje to potwierdzenie w Przedmowie do książki z roku 1877, w której czytamy: „Dopóki nie pojmie się, że transcendentalny sposób stawiania pytań tylko i wyłącznie jest w stanie wprowadzić filozofię na stałą drogę badania naukowego, opowiedzenie się za Kantem musi rozumieć jako dogmatyczne" 34 .

Książka zawierająca korespondencję Hermanna Cohena została uzupełniona spisem jego wykładów w latach 1872-1918. Są tam więc wykłady na Uniwersytecie w Marburgu oraz w Berlinie - Lehranstalt für die Wissenschaft des Judentums, gdzie Cohen wykładał po przejściu na emeryturę i opuszczeniu Marburga. Korespondencja została wzbogacona o przypisy wyjaśniające kwestie sporne, niejasne, niedopowiedzenia ze strony Cohena. Zawiera też obszerny indeks osobowy i przedmiotowy. To wszystko powoduje, że czytelnik otrzymuje ogromną dozę materiału badawczego, który pozwala lepiej zrozumieć samego Cohena, twórcę neokantowskiej szkoły marburskiej w jego początkach. Jego zmaganie się o habilitację, a następnie o pozycję w Marburgu. Tym bardziej, że z czasem miał do czynienia z narastającym antysemityzmem, co od Cohena wymagało zajęcia stanowiska.

29 Chodzi o J.H. Witte: Salomon Maimon. Die merkwürdigen Schicksale und die wissenschaftliche Bedeutung einej jüdischen Denkers aus der Kantischen Schule. Berlin 1876. Por. List nr 39 z dnia 27.10.1876. Hermann Cohen. Briefe an August Stadler..., s. 97.

30 J.H. Witte: Zur Erkenntnisstheorie und Ethik. 3 philosophische Abhandlungen. Berlin 1877.

31 List nr 48 z dnia 8.11.1877. Hermann Cohen. Briefe an August Stadler..., s. 111-114.

32 I. Kant: Krytyka czystego rozumu. T. 1. Tłum. R. Ingarden. Warszawa 1957, s. 21 (B VII).

33 I. Kant: Gesammelte Schriften. Bd. 3: Kritik der reinen Vernunft. Zweite Auflage 1787. Berlin 1911, s. 7.

34 H. Cohen: Kants Begründung der Ethik. Berlin 1877, s. IV. 
Pierwszym przejawem ten konieczności był tekst z roku 1880 zatytułowany Ein Bekenntniß in der Judenfrage ${ }^{35}$, który stanowił próbę polemiki z serią artykułów, których autorem był historyk Heinrich von Treitschke (1834-1896), uchodzący za autora sporu antysemickiego wywołanego w roku 1879 serią artykułów na łamach „Preußische Jahrbücher" 36. Pierwszy z tych tekstów ukazał się z datą 15 listopada 1879 roku i nosił tytuł Unsere Aussichten ${ }^{37}$.

Przedstawiona przez Hartwiga Wiedebacha korespondencja Hermanna Cohena skierowana do Augusta Stadlera stanowi niewyczerpane źródło wiedzy na temat początków neokantyzmu, czy też początków szkoły marburskiej. W świetle korespondencji Cohen zostaje przedstawiony jako myśliciel próbujący zinterpretować Kanta inaczej, niż ma to miejsce dotychczas. Stąd wynika zainteresowanie Langego i skierowanie Stadlera do Cohena, w rezultacie czego zrodziła się przyjaźń między tymi dwoma myślicielami. Konsekwencją tej znajomości było z kolei wskazanie przez Stadlera uwagi Langego na kłopoty, z jakimi borykał się Cohen. Z tego wyniknęła habilitacja w Marburgu i pozostanie w tym heskim miasteczku aż do emerytury, do czego przyczynił się pośrednio - ujawniający się pod koniec korespondencji - wzmagający się antysemityzm. Przedstawiona korespondencja staje się zrozumiała również dzięki przypisom, w jakie została zaoptarzona przez Wiedebacha.

Hermann Cohen. Briefe an August Stadler. Hrsg. von H. Wiedebach. Schwabe Verlag Basel 2015, ss. 172.

35 H. Cohen: Ein Bekenntniß in der Judenfrage. Berlin 1880.

36 List nr 54 z dnia 4.5.1880. Hermann Cohen. Briefe an August Stadler..., s. 121-124.

37 H. von Treitschke: Unsere Aussichten. „Preußische Jahrbücher” Hrsg. von H. von Treitschke. 1879, Bd. 44, s. 559-576. 